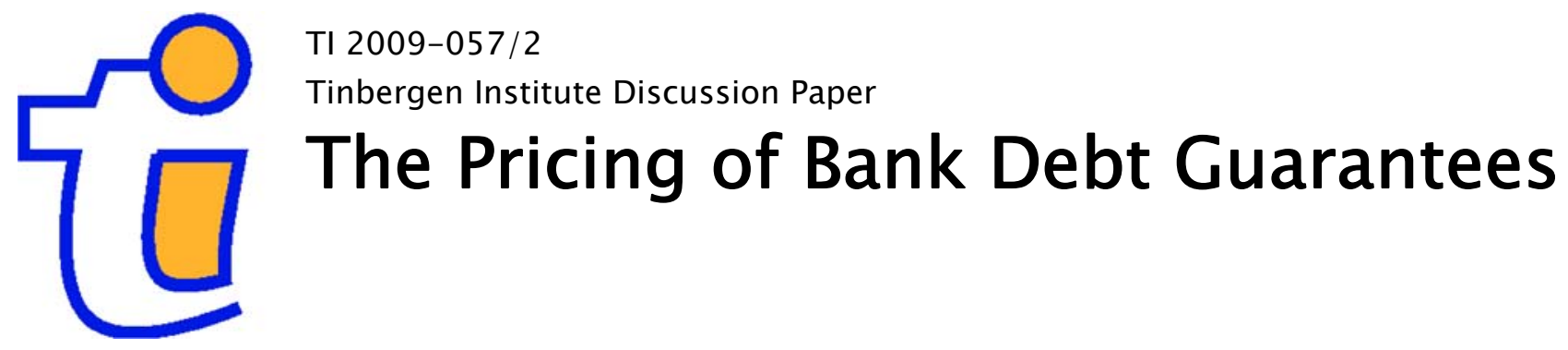

Stefan Arping

Amsterdam Business School, University of Amsterdam, and Tinbergen Institute. 


\section{Tinbergen Institute}

The Tinbergen Institute is the institute for economic research of the Erasmus Universiteit Rotterdam, Universiteit van Amsterdam, and Vrije Universiteit Amsterdam.

Tinbergen Institute Amsterdam

Roetersstraat 31

1018 WB Amsterdam

The Netherlands

Tel.: +31(0)205513500

Fax: $+31(0) 205513555$

Tinbergen Institute Rotterdam

Burg. Oudlaan 50

3062 PA Rotterdam

The Netherlands

Tel.: + $31(0) 104088900$

Fax: $+31(0) 104089031$

Most TI discussion papers can be downloaded at http://www.tinbergen.nl. 


\title{
The Pricing of Bank Debt Guarantees
}

\author{
STEFAN ARPING*
}

June 26, 2009

\begin{abstract}
We analyze the optimal pricing of government-sponsored bank debt guarantees within the context of an asset substitution framework. We show that the desirability of fair pricing of guarantees depends on the degree of transparency of the banking sector: in relatively opaque banking systems, fair pricing exacerbates banks' incentive to take excessive risks, whereas the opposite is true in relatively transparent banking systems.
\end{abstract}

JEL-codes: G21, G38

Keywords: Debt Guarantees, Fair Pricing, Financial Stability

\section{Introduction}

During the financial crisis of 2008, many governments initiated guarantee programmes under which certain classes of debt issued by banks will be guaranteed by governments or quasi-government bodies. ${ }^{1}$ A key design aspect of such programmes concerns the pricing of guarantees: should bank debt guarantees be "fairly" priced (i.e., self-financing) or should

*Amsterdam Business School, University of Amsterdam, Roetersstraat 11, 1018 WB Amsterdam, The Netherlands. e-mail: s.r.arping@uva.nl

${ }^{1}$ For an overview, see Orrick (2009). See Acharya and Richardson (2009) for an analysis of the causes behind and the policy responses to the financial crisis. 
they involve net subsidies to the banking sector? The aim of this note is to shed light on this question within the context of a simple model where bank risk-return profiles are subject to moral hazard.

We argue that the desirability of fair pricing of guarantees hinges critically on the degree of transparency of the banking sector. In relatively transparent banking systems, guarantee premia can and should be made sensitive to changes in banks' risk-taking. ${ }^{2}$ In such an environment, fair pricing is desirable as it maximizes the risk-sensitivity of guarantee premia, which in turn helps to contain banks' incentive to take excessive risks. By contrast, in relatively opaque banking systems, there is little scope for guarantee premia to adequately reflect banks' actual risk-taking. In this environment, levying guarantee premia on banks merely raises their effective debt burden. This in turn exacerbates banks' incentive to take excessive risks. Thus fair pricing of guarantees is desirable if and only if the banking system is sufficiently transparent.

The observation that subsidies to banks (e.g., underpriced deposit insurance) are at times efficiency-enhancing is central to the banking literature (see, e.g., Chan et al. 1992, Freixas and Rochet 1998, Hellmann et al. 2000, Blum 2002, Boyd et al. 2002, Morrison and White 2006). Our article complements this literature by suggesting that the desirability of fair pricing of guarantees may depend on the degree of transparency of the banking sector.

\section{Model and Analysis}

There is universal risk-neutrality and no discounting. At date 0, a bank with no assets in place requires funds $I>0$ to finance an investment portfolio (e.g., loans). Funding is to be

\footnotetext{
${ }^{2}$ In our static, one-period model this is accomplished by collecting premia ex post. In practice, this would mean that premia are regularly adjusted to reflect changes in banks' risk profiles (as is, e.g., the case with US deposit insurance).
} 
provided by government insured debt (e.g., deposits or FDIC insured unsecured debt). At date 1 , the bank chooses the risk-return profile of its asset portfolio, $X \in[0, \bar{X}]$. The bank is protected by limited liability and maximizes shareholder value. At date 2, the guarantee agency (e.g., the FDIC) observes a signal about the bank's risk-return profile (see below). At date 3, cash flows realize. The distribution of cash flows is

$$
\tilde{X}= \begin{cases}X & \text { with probability } \rho(X) \\ 0 & \text { with probability } 1-\rho(X)\end{cases}
$$

with $\rho^{\prime}(X)<0, \rho^{\prime \prime}(X) \leq 0$, and $\rho(\bar{X})=0$. Let $X^{F B}$ denote the welfare-maximizing level of risk. Abstracting from bankruptcy and other deadweight costs of bank failure, $X^{F B}$ maximizes $\rho(X) X$ and is characterized by

$$
\rho^{\prime}\left(X^{F B}\right) X^{F B}+\rho\left(X^{F B}\right)=0
$$

We assume $\rho\left(X^{F B}\right) X^{F B}>I$.

Information. The signal observed by the guarantee agency at date 2 is imperfect. Specifically, we assume that with probability $\lambda$ the agency can observe (and verify) the banker's actual risk choice $X$, while with probability $1-\lambda$ the signal is uninformative (so that all what the agency can do is to infer the bank's riskiness from the underlying game). Hence the agency's information set is

$$
X^{\mathrm{inf}}= \begin{cases}X & \text { with probability } \lambda \\ X^{*} & \text { with probability } 1-\lambda\end{cases}
$$

where $X^{*}$ denotes the equilibrium risk-return profile.

Guarantee Premia. In the event of bank failure, debtholders are bailed out by the guarantee agency. In exchange for this service, the agency levies a premium on the bank. To ensure that the premium can potentially reflect the bank's actual risk, we assume that the 
premium is due ex post. Consider in a first step a premium policy that is self-financing. If such a premium policy moreover made use of all available information, it would satisfy

$$
\left(1-\rho\left(X^{\mathrm{inf}}\right)\right) I=\rho\left(X^{\mathrm{inf}}\right) P
$$

where $P$ denotes the premium, the left hand side is the expected cost of the guarantee, ${ }^{3}$ and the right hand side are the agency's expected revenues. This guarantee is fairly priced in the sense that it is fully financed by the bank. The guarantee would be "unfairly" priced if the cost of the guarantee were assumed by the taxpayer. To allow for varying degrees of "fairness", we will consider guarantee premia of the following form:

$$
P\left(X^{\inf }\right)=(1-t) \frac{\left(1-\rho\left(X^{\inf }\right)\right) I}{\rho\left(X^{\text {inf }}\right)}
$$

where $t \in[0,1]$ is set by the government upfront. ${ }^{4}$ The term $1-t$ measures the extent to which the government wishes bank debt guarantees to be financed by banks themselves, rather than the taxpayer. For $t=0$, the guarantee is self-financing, while for $t=1$ it is fully financed by the taxpayer. For $t \in(0,1)$, the guarantee is financed by both banks and the taxpayer.

The Banker's Problem. The banker's problem is to maximize bank shareholder value, i.e.,

$$
X^{*}=\arg \max _{X} \lambda \rho(X)(X-[I+P(X)])+(1-\lambda) \rho(X)\left(X-\left[I+P\left(X^{*}\right)\right]\right)
$$

The first order condition is

$$
\rho^{\prime}\left(X^{*}\right)\left(X^{*}-\left[I+P\left(X^{*}\right)\right]\right)+\rho\left(X^{*}\right)-\lambda \rho\left(X^{*}\right) P^{\prime}\left(X^{*}\right)=0
$$

\footnotetext{
${ }^{3}$ Notice that debtholders do not demand a default premium since they are insured.

${ }^{4}$ We do not allow for arbitrary penalties or premia policies such as closing down banks or seizing shareholder returns following $X \neq X^{F B}$. Such policies, while potentially implementing the first best in our simple model, are unlikely to be feasible in practice (e.g., on political grounds). We also do not allow for $t<0$ or $t>1$.
} 
The term in squared brackets is the effective debt burden. This is the sum of bank debt and the guarantee premium. As is standard, an increase in the debt burden will induce the bank to take more risk. The last term of (1) depends on the risk-sensitivity of the premium. An increase in the risk-sensitivity of the premium will induce the bank to take less risk. Consider then the effect of an increase in $t$ (i.e., less fair pricing). On the one hand, an increase in $t$ reduces the debt burden (by reducing the premium), but on the other hand it makes the premium less risk-sensitive. Notice that the latter effect becomes more pronounced as the banking sector becomes more transparent (i.e., $\lambda$ increases). This observation is central to the following analysis.

The Government's Problem. We assume that taxation has no deadweight costs and the government's objective is to maximize total welfare. ${ }^{5}$ Thus the government's problem is to

$$
\max _{\left(t \in[0,1], X^{*}\right)} \rho\left(X^{*}\right) X^{*}
$$

subject to

$$
\rho^{\prime}\left(X^{*}\right)\left[X^{*}-I \frac{(1-t)(1-\lambda)+t \rho\left(X^{*}\right)}{\rho\left(X^{*}\right)}\right]+\rho\left(X^{*}\right)=0
$$

where (2) is the first order condition of the banker's problem. By inspection, $X^{*}$ is first best if and only if the second term inside the squared brackets is zero. This is the case if and only if the guarantee is fairly priced (i.e., $t=0$ ) and the banking sector is perfectly transparent, $\lambda=1$. For $\lambda<1$, (2) is binding and the equilibrium level of risk inevitably exceeds the first best level. ${ }^{6}$ Let $X^{*}(t, \lambda)$ denote the smallest solution of (2). The government's problem reduces to minimizing $X^{*}(t, \lambda)$ with respect to $t$. From the implicit function theorem, we

\footnotetext{
${ }^{5}$ We also assume that an equilibrium with investment exists and that investment is efficient in equilibrium.

${ }^{6}$ Evaluating (2) at $X^{F B}$ yields a term that is strictly positive. Hence, by concavity, $X^{*}>X^{F B}$.
} 
have $^{7}$

$$
\operatorname{sign}\left[\partial X^{*}(t, \lambda) / \partial t\right]=\operatorname{sign}\left[\lambda-\left(1-\rho\left(X^{*}(t, \lambda)\right)\right)\right]
$$

Let $\hat{\lambda}$ denote the unique fixed point solving $\lambda=1-\rho\left(X^{*}(t, \lambda)\right){ }^{8}$ By $(3), X^{*}(t, \hat{\lambda})$ does not depend on $t$ and, hence, $\hat{\lambda}$ does not depend on $t$ either. There thus is a threshold $\hat{\lambda}$ such that $X^{*}(t, \lambda)$ is strictly increasing in $t$ if $\lambda>\hat{\lambda}$ and strictly decreasing in $t$ if $\lambda<\hat{\lambda}$. In other words, in an opaque banking system $(\lambda<\hat{\lambda})$, fair pricing of guarantees exacerbates banks' incentive to take excessive risks, whereas precisely the opposite is true in a transparent banking system. Hence the following result:

Proposition 1 There is a threshold $\hat{\lambda}$ such that

(i) in relatively opaque banking systems $(\lambda<\hat{\lambda})$ guarantees should be funded by the government $(t=1)$. The equilibrium risk-return profile is characterized by

$$
\rho^{\prime}\left(X^{*}\right)\left[X^{*}-I\right]+\rho\left(X^{*}\right)=0
$$

and does not depend on $\lambda$.

(ii) in relatively transparent banking systems $(\lambda>\hat{\lambda})$ guarantees should be fairly priced $(t=0)$. The equilibrium risk-return profile is characterized by

$$
\rho^{\prime}\left(X^{*}\right)\left[X^{*}-I \frac{1-\lambda}{\rho\left(X^{*}\right)}\right]+\rho\left(X^{*}\right)=0
$$

and is strictly decreasing in $\lambda$. Furthermore, $\lim _{\lambda \rightarrow 1} X^{*}=X^{F B}$.

\footnotetext{
${ }^{7}$ The proof is as follows. Let $\varphi\left(X^{*}\right)$ denote the left hand side of (2). By assumption, $\varphi\left(X^{*}\right)=0$ has a solution. Since any such solution exceeds $X^{F B}$, the optimal solution is given by the smallest solution. Since $\varphi\left(X^{*}\right)$ is continuous in $X^{*}$ and $\varphi(0)>0$, it must be the case that $\varphi^{\prime}\left(X^{*}\right)<0$ at the smallest solution. From the implicit function theorem, $\partial X^{*} / \partial t=-\varphi_{t}\left(X^{*}\right) / \varphi^{\prime}\left(X^{*}\right)=-\left[\rho^{\prime}\left(X^{*}\right) I\left(1-\lambda-\rho\left(X^{*}\right)\right) / \rho\left(X^{*}\right)\right] / \varphi^{\prime}\left(X^{*}\right)$. Hence, $\operatorname{sign}\left[\partial X^{*} / \partial t\right]=\operatorname{sign}\left[\lambda-\left(1-\rho\left(X^{*}\right)\right)\right]$.

${ }^{8}$ Notice that $1-\rho\left(X^{*}(t, \lambda)\right)$ is continuous and decreasing in $\lambda$.
} 
The empirical prediction is that guarantee (or deposit insurance) underpricing should be more prevalent in opaque than in transparent banking systems. At the same time, opaque banking systems should be more prone to bank failures. This, however, does not imply that opaque banking systems would necessarily benefit from a switch to fair pricing.

\section{Conclusion}

We have analyzed the desirability of fair pricing of bank debt guarantees within the context of an asset substitution framework. The desirability of fair pricing hinges critically on the degree of transparency: in transparent banking systems, fair pricing is desirable, whereas in opaque banking systems it is not. A caveat to the latter result is that policies involving subsidies to banks may impair dynamic efficiency and foster ex ante moral hazard.

\section{References}

Acharya, V. and M. Richardson, eds., 2009, Restoring Financial Stability: How to Repair a Failed System. (John Wiley \& Sons, New York).

Blum, J., 2002, Subordinated Debt, Market Discipline, and Banks' Risk Taking, Journal of Banking and Finance 26, 1427-1441.

Boyd, J., C. Chang, and B. Smith, 2002, Deposit Insurance: A Reconsideration, Journal of Monetary Economics 49, 1235-1260.

Chan, Y-S., S. Greenbaum, and A. Thakor, 1992, Is Fairly Priced Deposit Insurance Possible?, Journal of Finance 47, 227-245. 
Freixas, X. and J. Rochet, 1998, Fair Pricing of Deposit Insurance. Is It Possible? Yes. Is It Desirable? No, Research in Economics 52, 217-232.

Hellmann, T., K. Murdock, J. Stiglitz, 2000, Liberalization, Moral Hazard in Banking, and Prudential Regulation: Are Capital Requirements Enough?, American Economic Review 90, $147-165$

Morrison, A. and L. White, 2006, Is Deposit Insurance a Good Thing, and if so, Who Should Pay for It?, Mimeo, University of Oxford.

Orrick, 2009, Review of Worldwide Government Initiatives of 2008 to Guarantee Financial Institution Obligations, Orrick Client Alert, January 5, 2009. 